\title{
Konsekwencje zmian polityczno-ekonomicznych w Rosji po upadku komunizmu
}

$\mathbf{R}_{\text {ksja jest państwem o bogatej historii i różnorodnej kulturze }{ }^{1} \text {. Obecny }}$ cjalistycznego Republik Radzieckich (ZSRR). Rosja przejęła najistotniejsze problemy dawnego mocarstwa. ZSRR, stosując terror państwowy, neutralizował wszelkie niepokoje i konflikty społeczne. Po upadku komunizmu, stosując demokratyczne metody negocjacji, niemożliwe jest pogodzenie interesów poszczególnych narodów zamieszkujących obszar byłego ZSSR. Powstają wątpliwości dotyczące losów społeczeństwa rosyjskiego, które w przeszłości nie funkcjonowało na zasadach demokratycznych.

W Rosji istotne znaczenie odgrywa wielowiekowa tradycja - wykorzystana w odpowiedni sposób, może posłużyć jako narzędzie zmian w gospodarce i polityce bądź odwrotnie - może przyczynić się do umocnienia ortodoksyjności społeczeństwa, hamując rozwój cywilizacyjny na wiele lat.

Rosją przez wieki rządzono z centralnego ośrodka władzy. Przy niskiej świadomości społeczeństwa realną władzę sprawowali lokalni urzędnicy. Wielokrotnie próbowano poprawić sposób sprawowania rządów poprzez wzmocnienie władzy centralnej. Trudne jest wypracowanie odpowiedzi na pytanie, czy Rosjanie - wyróżniając się dotychczas zbiorową biernością - są w stanie sprostać wymaganiom właściwym dla społeczeństwa obywatelskiego?

Gospodarka rosyjska długo opierała się na systemie feudalnym. Początki kapitalizmu zostały zniszczone przez komunistyczny model gospodarki, dążącej do stworzenia autarkii w ramach bloku państw socjalistycznych.

Hipotezą badawczą niniejszego studium są następujące twierdzenia:

1 Por. A. Chodubski, Elementy identyfikacji kulturowej Rosji, „Sprawy Polityczne" 2001, nr 3, s. 80-97. 
1. Rosja tworzy podstawy do rozwoju gospodarki rynkowej, jednak proces ten jest mało dynamiczny i nie objął zasięgiem wszystkich dziedzin gospodarki.

2. Nie istnieją przesłanki wskazujące na kształtowanie się w Rosji społeczeństwa obywatelskiego. Tradycja odgrywa znaczącą rolę w postrzeganiu relacji między elementami i instytucjami społecznymi.

3. Polityka zagraniczna Kremla nie jest jednoznacznie sprecyzowana, nie wypracowano przejrzystej strategii i jasno określonych celów.

W celu rozwinięcia hipotezy postawiono następujące pytania badawcze:

1. W jaki sposób nastroje społeczne powstałe w okresie panowania komunizmu oraz po jego upadku mogą wpłynąć na kształt dalszych reform w Rosji?

2. Jak rozwija się gospodarka rynkowa w państwie, które przez ponad 70 lat było poddane nakazowo-rozdzielczemu systemowi gospodarowania? Czy rozkwit gospodarki rynkowej jest w stanie umocnić demokrację?

3. Jaką rolę odegra Cerkiew prawosławna w procesie integracji Rosji? Jakie będą uwarunkowania rozwoju innych religii i wyznań?

4. Dlaczego władza powinna być oparta na autorytecie przywódcy? W jaki sposób tradycja przyczyniła się do postrzegania władzy w Rosji? Czy Władimir Putin, prezydent Rosji od 1999 r., przystaje do wykreowanego przez media wizerunku?

5. Jakie państwo postrzega się jako strategicznego partnera Rosji? W jaki sposób polityka surowcowa kreuje podstawy polityki zagranicznej? Gdzie Rosja buduje strefę buforową?

W analizie problemu posłużono się metodą politologiczną, z elementami metodologii porównawczej, poznania historycznego, analizy systemowej i instytucjonalno-prawnej ${ }^{2}$.

Upadek ZSRR stanowił przełomowe wydarzeniem w dziejach świata ${ }^{3}$. Polityka międzynarodowa przestała opierać się na rywalizacji Stanów Zjednoczonych Ameryki (USA) z ZSRR. Jedynym liczącym się mocarstwem pozostało USA, państwo z rynkową gospodarką i obywatelskim społeczeństwem ${ }^{4}$. Rosja - największy kraj powstały po rozpadzie ZSRR -

2 A. Chodubski, Wstęp do badań politologicznych, Gdańsk 1995, s. 72-82.

3 J. Kukułka, Historia współczesna stosunków międzynarodowych 1945-1994, Warszawa 1994, s.504-510.

4 Por. S. Huntington, Zderzenie cywilizacji, Warszawa 2001. 
przejęła problemy dawnego mocarstwa. Do najważniejszych z nich należą: niska wydajność pracy w gospodarce, niedostateczne wykorzystanie surowców, niezdolność rolnictwa do zaspokojenia potrzeb żywnościowych społeczeństwa (konieczny import produktów rolnych), niska moralność społeczeństwa przejawiająca się powszechną korupcją i alkoholizmem, gwałtownie uwidaczniające się problemy narodowościowe ${ }^{5}$. Nowym problemem jest malejąca populacja. Murray Fesfbach, amerykański demograf, specjalista od spraw Związku Radzieckiego i współczesnej Rosji twierdzi, że ludność Rosji zmniejsza się rocznie o 750 tys. osób ${ }^{6}$. Na zaistniałą sytuację złożyły się następujące procesy: kryzys życia rodzinnego, aborcja, która przybrała znaczne rozmiary, zwiększony dostęp kobiet do edukacji i wzrost świadomości obywateli ${ }^{7}$.

Sytuacja ekonomiczna służby zdrowia ulega systematycznemu pogorszeniu; rosyjskie szpitale uważane są za miejsca niebezpieczne - pobyt w nich grozi możliwością zachorowania na żółtaczkę. Kobiety i dzieci nie mają zapewnionej odpowiedniej opieki zdrowotnej. Wzrosła umieralność mężczyzn z powodu alkoholizmu i nienależytej higieny życia. Wskazane czynniki decydują o zapaści demograficznej. Jedyną możliwość zmiany tej niekorzystnej sytuacji stwarza wzrost gospodarczy, wpływający na podniesie standardu życia obywateli, a tym samym - skłaniający ich do zakładania rodzin ${ }^{8}$.

Komunizm zablokował w świadomości ludzi chęć poszerzania wiedzy i horyzontów myślowych. Władza nie przykładała większej wagi do poziomu wykształcenia obywateli. Zadziałał następujący mechanizm myślenia: społeczeństwo niewykształcone - w przeciwieństwie do wyedukowanego - jest mniej skłonne do przeciwstawienia się elicie rządzącej. Ze względów ideologicznych ograniczono dostęp do rzetelnej informacji w dziedzinie nauk społecznych i humanistycznych. Kreml wykazywał wzmożone zainteresowanie naukami technicznymi, które bezpośrednio przyczyniały się do rozwoju myśli konstrukcyjnej i zbrojeniowej.

5 R. Peterfoff, Obstacles to the Transformation of the Soviet Economy, „Aussenpolitik" 1991, nr 3, s. 221-230; Z. Madej, Rosyjskie zmagania cywilizacyjne, Warszawa 1993, s. 160-169; W. Stankiewicz, Zasada integralności terytorialnej wobec prawa narodów do samostanowienia w kontekście stosunków rosyjsko-czeczeńskich, The rule of Territorial Integrity and the Right of Nations to Soverignty in the Context of Chechnya-Russia Relations, „Athenaeum Political Science” 2002, nr 9, s. 9-28.

6 P. Kennedy, Ostatni Rosjanin, „Wprost” 2002, nr 25, s. 98.

7 Tenże, Mocarstwa Świata, Warszawa 1994, s. 481-482.

8 Ibidem, s. 98-99. 
Problemy pokolenia współczesnego w adaptacji do wymogów nowoczesnego systemu rynkowego, wynikające $\mathrm{z}$ braku wiedzy o elementarnych mechanizmach wymiany zasobów i towarów w warunkach konkurencji ${ }^{9}$, są konsekwencją polityki ograniczającej obywatelom swobodę intelektualnego rozwoju.

Komunistyczna Partia Federacji Rosyjskiej (KPFR), spadkobierczyni Komunistycznej Partii Związku Radzieckiego, spotkała się z marginalnym zainteresowaniem Rosjan; partia ta deklaruje niewielkie poparcie dla polityki Kremla. Znaczna część aktywistów odeszła z partii, a dodatkowo kierownictwo wyklucza aktywnych działaczy za popieranie polityki bloku pro-prezydenckiego. Gleb Pawłowski, politolog, były doradca W. Putina twierdzi, że w Rosji powinien powstać system dwupartyjny charakteryzujący się silną prawicą i lewicą. Rolę stronnictwa prawicowego pełni Jedność Rosji, a prawdopodobnie misję utworzenia lewicowej super-partii otrzyma Giennadi Sieleznow, przewodniczący Dumy, wykluczony z KPFR ${ }^{10}$. Osłabienie komunistów ułatwi rządowi wprowadzenie niezbędnych ustaw. Propozycja G. Pawłowskiego może stanowić początek likwidacji opozycji w Rosji ${ }^{11}$.

Symbolami minionej epoki są: hymn ZSRR, obecnie Rosji, nazwy ulic noszące nazwiska rewolucjonistów, pochody pierwszomajowe, przyciagające niewielką liczbę uczestników. W manifestacjach biorą udział głównie emeryci lub młodzież o skrajnych poglądach nacjonalistycznych.

Armia Czerwona, w myśl ideologii komunistycznej, sprawowała funkcję reprezentacyjną. Załamanie potęgi radzieckiej skutkowało wycofaniem wojsk z Europy i części ZSRR (Ukrainy, Kazachstanu) ${ }^{12}$. Upadek ZSRR wymusił zmniejszenie liczebności armii - z ponad 4 milionów żołnierzy do miliona. Państwo nie zapewniło godziwych warunków egzystencji odchodzącej kadrze; część byłych czerwonoarmistów stała się żołnierzami najemnymi, zwanymi „kontraktnikami”, gotowymi podjąć walkę z pobudek ekonomicznych. O „kontraktnikach” słyszy się w objętych konfliktami zbrojnymi regionach byłego Związku Radzieckiego, a także w Serbii i w Afganistanie ${ }^{13}$.

9 B. Mach, Transformacja ustrojowa a mentalne dziedzictwo socjalizmu, Warszawa 1998, s. 104.

10 G. Ślubowski, Sieroty po Leninie, „Wprost” z dn. 16.06.2002, nr 24, s. 110.

11 Ibidem, s. 110-111.

12 P. Bracken, Pożar na Wschodzie, Warszawa 2000, s. 134-135.

13 Tenże, Żotnierze Fortuny, „Wprost” 2001, nr 47, s. 102-103. 
Rosja dysponuje arsenałem broni nuklearnej, chemicznej i biologicznej wyprodukowanej w czasie zimnej wojny. Ilość oraz siła rażenia miały zmusić państwa Zachodnie do uległości politycznej oraz stworzyć iluzoryczną przewagę Rosji. Po upadku ZSRR broń stała się zbędna i niebezpieczna, gdyż mogła znaleźć nabywców wśród terrorystów lub tzw. państw bandyckich. Niebezpieczeństwo niesie z sobą fakt, że Rosji nie stać na właściwe i skuteczne zabezpieczenie magazynów z bronią. W tej sytuacji dodatkowe niebezpieczeństwo stanowi możliwość korupcji służb zabezpieczających obiekty ${ }^{14}$. USA przekazuje Rosji środki przeznaczone na pomoc w odpowiednim składowaniu broni, jednakże znaczna część tych funduszy ulega defraudacji.

Komunizm, jako praktyka rządzenia i ustrój, ukształtował się w Rosji w oparciu o rosyjską tradycję i zachodnią ideologię - marksizm. Bolszewicy wzmocnili rosyjskie dążenia imperialne, samowładztwo i wzory biurokratyczne funkcjonujące w świadomości urzędników. Zapobiegli kształtowaniu się społeczeństwa obywatelskiego, którego oznakami były samorządy ziemskie, niezależne od carskiej władzy ${ }^{15}$.

Rosjanie przez lata byli przyzwyczajeni do sytuacji, w której państwo za pomocą służb administracyjnych zapewnia byt i zaspakaja elementarne potrzeby ${ }^{16}$. Obywatele zostali pozbawieni indywidualności na rzecz kolektywności; poza tym hamowano ich przedsiębiorczość. Tworzone normy i metody pracy uprzedmiotowiły relacje międzyludzkie.

Rosja została dotknięta kryzysem ideologicznym, postimperialnym, społecznym i biologicznym. Sytuacja wewnętrzna nie stwarza właściwej potrzeby transformacji gospodarczej i politycznej ${ }^{17}$. Pewny wydaje się fakt, że komunizm się nie odrodzi - Rosjanie nie będą skłonni zrezygnować ze swobód i praw, które nabyli w okresie transformacji, poza tym wprowadzone w państwie podstawy gospodarki rynkowej wykreowały w światopoglądzie obywateli alternatywny model gospodarki, skupiony na zaspokajaniu potrzeb konsumenta i nieznający sytuacji niedoboru.

Rosyjska elita polityczna, a także intelektualiści, dotkliwie przeżywali utratę mocarstwowej i imperialnej pozycji Rosji. Kwiat społeczeństwa nie potrafił stworzyć alternatywnej wizji rozwoju, która odpowiadałaby geo-

14 P. Bracken, op. cit, s. 112-117.

15 J. Karpiński, Trzecia niepodległość, Warszawa 2001, s. 122.

16 Profile wieku, pod red. B. Wildsteina, Warszawa 2000, s. 47.

17 Ibidem, s. 60. 
strategicznej pozycji kraju i prowadziła do konsolidacji rosyjskiego społeczeństwa ${ }^{18}$.

Wśród elity intelektualnej powstał podział na słowianofilów i zapadników. Każda z grup rości sobie prawo do wyznaczania drogi rozwoju społeczności Rosji. Słowianofile postrzegają Rosję wśród państw azjatyckich i upatrują sojuszników wśród państw Azji; widząc w kapitalizmie zagrożenie powstawaniem zbyt znaczących różnic społeczno-ekonomicznych, proponują równość społeczną. Słowianofile głoszą, że relacje międzyludzkie powinny być oparte na związkach emocjonalnych i autorytecie, a nie na prawie, jak w państwach Zachodu. Rząd winien działać zgodnie z zasadą patriarchalnego autorytetu i nie dopuszczać do powstania nierówności społecznych ${ }^{19}$ - sądzi Richard Pipes, amerykański rusycysta i historyk, profesor Harvard University.

Sposób postrzegania rzeczywistości nie stwarza realnych podstaw analizy problemu. Powstają wątpliwości, czy Rosjanie zgodzą się na próbę praktycznego zastosowania zasady powszechnej równości. Zapadnicy proponują przeciwną koncepcję powiązania Rosji z Zachodem, stwarzając możliwość sięgnięcia po nowoczesną technologię. Spór między dwiema grupami zintensyfikował się po upadku ZSRR. W okresie komunizmu, ze względu na dążenia władz do scalenia narodów ZSRR w jeden naród radziecki, rywalizujące stronnictwa nie miały możliwości zaistnienia na forum. Kreml, miast skupiać się na budowie „Imperium Słowiańskiego” czy realizacji powstałej w XVIII w. koncepcji „Moskwa Trzecim Rzymem”, poszukiwał sojuszników wśród innych państw demokracji ludowej, powiększając zarazem strefę wpływów.

Dyskusje na temat przyszłości Rosji ożyły na Zachodzie za sprawą Aleksandra Sołżenicyna, laureata literackiej Nagrody Nobla, uznawanego za duchowego przywódcę słowianofilów, współcześnie postrzeganego jako postać anachroniczna, niewywierająca realnego wpływu na poglądy rodaków, wykazujących bierną postawę wobec sporów światopoglądowych.

Przeciętny Rosjanin przyjmuje, że każdy rząd dopuszcza się korupcji, a przeciętny obywatel wzoruje się na rządzących ${ }^{20}$. Korupcja nie jest odchyleniem od fundamentów ustrojowych, a konstytutywnym elementem kształtującego się od wieków systemu.

18 Rosja i jej squsiedzi, pod kier. nauk. G. Przebinda, Kraków 2000, s. 12.

19 Profile wieków ..., s. 52.

20 Ibidem, s. 51. 
Na prowincji władza rozumiana jest personalnie, a walka odbywa się nie między partiami politycznymi, a klanami reprezentującymi poszczególne grupy interesów, powiązanymi z organami administracji państwowej i strukturami gospodarczymi oraz finansowymi ${ }^{21}$. Rosjanie nie wierzą w programy polityczne czy obietnice polityków, jednakże wykazują zdolność do zaufania człowiekowi o silnej osobowości, potrafiącemu skłonić obywateli do wiary w możliwość zaprowadzenia porządku i wzięcia odpowiedzialności za wszelkie działania władz. Polityk, który ograniczy przestępczość może liczyć na poparcie społeczne. Szczególne zaufanie wynika z tradycji i panujących zwyczajów. Rosjanie utożsamiają porządek z prawem, rząd powinien więc za pomocą podległych mu instytucji państwowych rozstrzygać spory i podejmować decyzje. Niepodporządkowanie się władzy postrzegane jest jako zjawisko naganne i wymagające poniesienia kary. Potrzeba porządku przyczynia się do akceptacji reform postrzeganych jako odpowiednie i słuszne. Wątpliwości budzi kwestia krytyki, która wydaje się być niemoralna i nieodpowiednia z punktu widzenia tradycji.

Tradycja rosyjska powoduje, że wraz z ograniczeniem funkcjonowania władzy centralnej, przestaje sprawnie działać całe państwo ${ }^{22}$ - twierdzi Pipes. Rosja nigdy nie była sprawnie zarządzana ze względu na znaczną powierzchnię, niedostatecznie rozwiniętą infrastrukturę komunikacyjną oraz niedojrzałość polityczną gubernatorów, którzy partykularne interesy stawiali nad ogólnonarodowymi wartościami. Obowiązywała jedna nieformalna zasada, objawiająca się narastaniem samowładzy lokalnych pryncypałów przy jednoczesnym oddalaniu się od Moskwy.

Skuteczne panowanie w Rosji może zapewnić jedynie silna władza na Kremlu, skupiona $\mathrm{w}$ rękach haryzmatycznego przywódcy ${ }^{23}$. Federalny ustrój nie jest dla Rosji odpowiedni, gdyż poziom świadomości demokratycznej jest nadal niski. Kreml nie zezwolił na radykalną decentralizację władzy w obawie przed separacją krajów od państwa. W czasach komunizmu nie dążono do asymilacji podbitych narodów - zezwalano na ograniczone kultywowanie zwyczajów poszczególnych nacji. Rosja uniknęła buntów i wystąpień narodów azjatyckich. Istniało realne zagrożenie, że wraz z rozwojem cywilizacyjnym narody zaczną domagać się niepodległości. Koniecznym działaniem było zacieśnienie kontroli nad społeczeń-

21 Rosja i jej sqsiedzi ..., s. 90.

22 Profile wieków ..., s. 47.

23 Rocznik strategiczny 2001/2002, Warszawa 2002, s. 193-194. 
stwem. Z sytuacją skutecznie radziły sobie władze ZSRR, prowadząc działania zmierzające do utworzenia jednolitego społeczeństwa radzieckiego, odwołującego się do kultury socrealizmu i historii, której początek upatruje się w 1917 r. Władza podejmowała decyzję o przesiedleniu ludności, oddzielając narody od rdzennych terytoriów.

Analizując sytuację polityczną w Rosji, uwidacznia się podział na kilka społeczeństw. Społeczeństwo wielkich miast reprezentuje odmienne wartości i kulturę niż ludność zamieszkująca na wsi i na prowincji; jedni głosują na liberałów, drudzy na działaczy komunistycznych i wywodzących się z nich nacjonalistów ${ }^{24}$.

Sytuacja jest korzystna dla reform społeczno-politycznych - władze oczekują akceptacji polityki opartej na współpracy z innymi państwami.

Upaństwowienie środków produkcji w ideologii komunistycznej służyło likwidacji własności prywatnej, będącej źródłem zróżnicowania społeczeństwa pod względem posiadanego majątku i władzy. Komunizm natrafił w Rosji na podatny grunt ze względu na istnienie realnych stosunków feudalnych. Na przełomie XIX i XX w. w Rosji zaczęły pojawiać się fabryki, które przyjmowały ludzi migrujących ze wsi do miast. Postępowało niezadowolenie wynikające $\mathrm{z}$ wyzyskiwania pracowników przez właścicieli fabryk, często obcokrajowców.

Poprzez gospodarkę nakazowo-rozdzielczą realizowano politykę władz, zmierzającą do ekspansji ideologicznej i terytorialnej. Komuniści znacjonalizowanym fabrykom zlecali masową produkcję broni. Zbrojenie pozostawało priorytetowym elementem produkcji, w niewielkim stopniu przyczyniającym się do rozwoju cywilizacyjnego społeczeństwa, które rezygnowało z konsumpcji. W zamian obywatele otrzymywali poczucie przynależności do mocarstwa, powoli chylącego się ku upadkowi; poczucie to często było bezwartościowe, gdyż nie przekładało się na wymierne korzyści społeczne. Istotne decyzje podejmowali funkcjonariusze partyjni, zajmujący najwyższe stanowiska - ludzie u szczytu władzy nie baczyli na uwarunkowania lokalne. Precedens doprowadził do nieprzejrzystości struktury organów decyzyjnych ${ }^{25}$.

W połowie lat 80-tych czytelne były symptomy kryzysu. W Europie Środkowo-Wschodniej rządy komunistyczne utraciły autorytet społeczeństwa; faktem stawała się konieczność zmian ustrojowych. ZSRR utracił

24 Ibidem, s. 51.

25 J. Karpiński, op. cit., s. 123. 
moc oddziaływania na państwa komunistyczne. W 1985 r. pierwszym sekretarzem KPZR został Michaił Gorbaczow. Wprowadził on pakiet reform: pierestrojkę, głasnost i uskorienie, których celem było nadanie socjalizmowi nowoczesnej formy w sferze życia społecznego oraz stworzenie wrażenia otwartości w działaniu organizacji społecznych i politycznych $^{26}$. Z efektów reform korzystali ludzie, których dotychczas nazywano dysydentami. Zmiany przyczyniły się do wzmożonego powstawania nieformalnych ugrupowań. Pojawiły się czasopisma, które nie podlegały cenzurze: „Głasnost”, „Ekspres Kronika”.

Reformy nie spełniły pokładanych w nich oczekiwań. Społeczeństwo nie zostało przygotowane na wzmożony przepływ informacji, urzędnicy nie dostosowali się do rozporządzeń, w wyniku osłabienia polityki represji odradzały się konflikty etniczne i wyznaniowe ${ }^{27}$.

Początek lat 90-tych stanowi okres burzliwych przemian ustrojowych. W marcu 1990 r. odrzucono zasadę kierowniczej roli partii. W czerwcu 1991 r. prezydentem Federacji Rosyjskiej został Borys Jelcyn, uważany za polityka stojącego w opozycji do KPZR i ekipy Gorbaczowa. Dwa miesiące później rozwiązaniu uległ Układ Warszawski, pakt polityczno-militarny powstały w $1955 \mathrm{r}$. w celu solidarnej obrony przed ewentualnym atakiem ze strony państw zachodnich. Próbą przywrócenia starego porządku był pucz Janajewa, nazwany od nazwiska lidera przewrotu, wiceprezydenta ZSRR. W konsekwencji nastapiło umocnienie władzy B. Jelcyna, który ogłosił się zwierzchnikiem sił zbrojnych ZSRR oraz przejął kontrolę nad przedsiębiorstwami i organami administracji państwowej. Władze komunistyczne utraciły możliwość oddziaływania na sytuację w państwie. Zdelegalizowano działalność KPZR, a 25 grudnia $1991 \mathrm{r}$. M. Gorbaczow ustapił $z$ urzędu prezydenta ${ }^{28}$.

W celu zacieśnienia współpracy niepodległych państw powstałych po rozpadzie ZSRR, powołano 21 grudnia $1991 \mathrm{r}$. Wspólnotę Niepodległych Państw, jednoczącą dotychczasowe republiki byłego mocarstwa, z wy-

26 J. Stańczyk, Przeobrażenia międzynarodowego układu sił w Europie, Warszawa 1999 , s. $180,183-184$.

27 W. Stankiewicz, Uwarunkowania polityczno-militarne federacji rosyjskiej a bezpieczeństwo międzynarodowe, w: Historia i bibliologia. Księga dedykowana pamięci doktora Zdzisława Konstantego Jagodzińskiego (1927-2001), pod red. J. Farysia, M. Szczerbińskiego, Gorzów Wlkp. 2005, s. 393-410.

28 Najnowsza Historia Świata, red. A. Patyka, J. Rydla, J. Rydla, Kraków 2000, t. 3, s. 89-91. 
jątkiem Litwy, Łotwy, Estonii oraz Gruzji. Komuniści i nacjonaliści upatrywali we Wspólnocie Niepodległych Państwa narzędzie restauracji byłego imperium. Posiedzenia wspólnoty przybierały charakter buntu „wszystkich przeciw Rosji” i straciły merytoryczne podstawy w procesie integracji republik byłego ZSRR. Większość postanowień integracyjnych pozostawała wyłącznie w sferze niespełnionych deklaracji politycznych. Rosja podpisywała układy bilateralne, będące odpowiedzią na zastój w procesie konsolidacji. Efektem współpracy był powstały w $1995 \mathrm{r}$. Związek Celny łączący Rosję, Kazachstan, Białoruś i Kirgistan ${ }^{29}$.

Rosjanie stanęli przed problemem przebudowy państwa, która zasięgiem objąć miała wszystkie dziedziny życia. Pakiet wprowadzonych reform był niekompletny; sprawą priorytetową była rynkowa transformacja gospodarki, nie uwzględniono natomiast mechanizmów i skutków przejścia do odmiennego systemu gospodarczego, co z kolei uczyniono w Pol$\mathrm{sce}^{30}$. Znaczna część społeczeństwa odniosła wrażenie braku perspektyw bytu społecznego - do kręgu niezadowolonych należeli niewykształceni obywatele oraz mieszkańcy wsi ${ }^{31}$. Grupę, która dostosowała się do otaczającej rzeczywistości stanowili młodzi ludzie pochodzący z dużych miast oraz osoby sprawujące funkcje kierownicze w państwowych przedsiębiorstwach. W krótkim czasie zbudowali oni wielkie imperia finansowe, opierające się w przeważającej części na współpracy z państwem. Dwunastu najbogatszych Rosjan zgromadziło majątek wart łącznie prawie 20 miliardów dolarów. Miejsce Borysa Bieriezowskiego, pierwszego milionera postradzieckiego kapitalizmu, zajmują młodsi i agresywniejsi biznesmeni: M. Chodorowski, właściciel Jukosu - kompani naftowej, R. Abramowicz, który osiagnął korzyści majątkowe z eksploatacji ropy i aluminium, O. Dieripaska kontrolujący Rosyjskie Aluminium ${ }^{32}$. Geneza imperiów sięga byłych przedsiębiorstw państwowych zajmujących się eksploatacją surowców, które nabyli od państwa obecni właściciele po cenie znacznie niższej od rynkowej. W wielu przypadkach przed nabyciem przedsiębiorstwa pełnili oni istotne funkcje kierownicze. Do magnatów dołączyli przedstawiciele działów gospodarki nierozpowszechnionych w komunizmie, m.in. bankowości - W. Poganin został szefem Onek-

29 Rosja $i$ jej sqsiedzi, op. cit., s. 20.

30 J. Karpiński, op. cit., s. 70-71.

31 A. Sołżenicyn, Rosja w zapaści, Warszawa 1999, s. 16-18.

32 J. Piński, K. Trębski, Państwo krezusi, „Wprost” z dn. 20.10.2002, nr 42, s. $40-48$. 
sim-Banku, mediów - W. Gusinski, posiadający prawo do stałego pobytu w Tel Awiwie, stanął na czele Media-Most ${ }^{33}$.

W czasie rządów Borysa Jelcyna w Rosji realną władzę sprawowało 89 gubernatorów, którzy - ze względu na posiadanie udziałów w zbywanych przez państwo przedsiębiorstwach - wykazywali zainteresowanie postępującym procesem prywatyzacji. Zaczęła powstawać klasa oligarchów, prywatnych posiadaczy środków produkcji i korporacji eksploatujących surowce naturalne. Zrodziło się realne zagrożenie, że potentaci związani z władzą postkomunistyczną, posiadający rozległe kontakty polityczno-ekonomiczne, będą przedkładali partykularne interesy ponad dobro państwa, podejmując działania na jego szkodę. Ludzie ci zabiegali o znaczne wpływy, niejednokrotnie posługując się groźbą czy siłą. Powstało niebezpieczeństwo, że skorumpowani urzędnicy zaczną sprzedawać cenne informacje, a zastraszeni ministrowie podpisywać umowy prywatyzacyjne, doprowadzając do powszechnej anarchii ustrojowej.

Po upadku komunizmu gospodarka rosyjska znalazła się w stanie permanentnej stagnacji. Skumulowany spadek PKB w latach 1990-1997 wyniósł ponad $50 \%$. Postępowała wymiana barterowa; zaczęto posługiwać się alternatywnymi środkami płatniczymi (wekslami, skryptami dłużnymi, przyrzeczeniami zapłaty), które były rezultatem masowego unikania płatności podatkowych. Restrykcyjna polityka monetarna i niestabilne ograniczenia budżetowe doprowadziły do kryzysu finansowego, którego symptomy pojawiły się w połowie $1998 \mathrm{r}$. w postaci spadku eksportu i pogarszającego się rachunku obrotów bieżących, realnej aprecjacji rubla, napływu krótkookresowego kapitału finansowego, dużego deficytu budżetowego i groźby utraty płynności przez banki ${ }^{34}$.

Jelcyn, walcząc o wpływy na Kremlu, nie podejmował radykalnych reform, gdyż powstałe niepokoje i bunty społeczne mogłyby posłużyć jako pretekst do odsunięcia prezydenta od władzy. Transformacje przebiegały na zasadzie „dostrajania” gospodarki. Precedensem stało się odraczanie trudnych decyzji politycznych. Rezultatem zachowawczego działania był brak skoordynowanej polityki monetarnej i fiskalnej, utrzymywanie wysokiego deficytu, który prowadził do spirali zadłużenia ${ }^{35}$.

W 1995 r. prezydent zdecydował się na użycie siły przeciw Radzie Najwyższej, aby zachować umiarkowany charakter polityki gospodar-

33 Ibidem, s. 48-50.

34 Rosja $i$ jej sqsiedzi ..., s. 69-76.

35 Ibidem, s. 76-77. 
czo-społecznej państwa. Jelcyn, ze względu na stan zdrowia, stopniowo przestawał kontrolować sytuację polityczną w kraju. Efektem niemocy prezydenta była pierwsza w historii Rosji próba wszczęcia procedury odsunięcia go od władzy. Ostatecznie wniosek nie uzyskał odpowiedniego poparcia w Dumie, jednak cała sytuacja stanowiła potwierdzenie osłabienia ośrodka władzy i systemu politycznego ${ }^{36}$.

Prezydent, mając na względzie nieprzychylność klasy politycznej, 31 grudnia 1999 r. złożył rezygnację z urzędu. Ustępując wyraził wolę, by „prezydentem Rosji został człowiek, który będzie kontynuował reformy demokratyczne, który nie zwróci kraju ku totalitaryzmowi i zapewni Rosji rozwój cywilizacyjny" ${ }^{\text {37 }}$. Uwzględniając doświadczenie i zdolności kandydatów na urząd głowy państwa, następcą wyznaczył premiera W. Putina, który w marcu 2000 r. wygrał przedterminowe wybory prezydenckie, legitymując władzę. Nowy prezydent, przedstawiając program reform gospodarczych, przystapił do odbudowy i umacniania sprawowanego urzędu.

Pierwszym rewolucyjnym posunięciem prezydenta było wprowadzenie $13 \%$ podatku liniowego od dochodów osób fizycznych. Doprowadziło to do zwiększenia ściągalności należności podatkowych o 50\%. Drugim istotnym przedsięwzięciem była dewaluacja rubla, która spowodowała poprawę opłacalności eksportu i produkcji na rynek wewnętrzny. Odsunięto w czasie reformę obrotu ziemią, którą ostatecznie wprowadzono w lipcu 2002 r. „Reformy zapewniły wzrost gospodarczy na poziomie 5,5\% rocznie, stawiając Rosję wśród dziesięciu najbardziej rozwijających się państw świata. Tempo wzrostu gospodarczego nie jest uzależnione od zmian cen ropy naftowej ${ }^{38, " ~-~ s a ̨ d z i ~ W . ~ S o r o k i n, ~ w i c e d y r e k t o r ~ I n s t y t u t u ~}$ Ekonomii Rosyjskiej Akademii Nauk. Powstają wątpliwości, czy Rosja jest niezależna od cen surowca. Wysoka cena ropy ułatwiła w 1998 r. wyjście państwa z kryzysu gospodarczego. Obniżka ceny o 1 USD kosztuje Rosję około 0,3 PKB, czyli przychody z eksportu są mniejsze o 2 mld USD, natomiast o 1 mld USD zmniejszają się dochody federalne ${ }^{39}$.

Wzrost ceny surowca wywiera bezpośredni wpływ na wzrost i rozwój gospodarczy. Największe rosyjskie koncerny branży paliwowej są skłon-

36 B. Jelcyn, Prezydencki maraton, Warszawa 2001, s. 2.

37 Ibidem, s. 33.

38 G. Ślubowski, Putin I Wielki, „Wprost” 2001, nr 51, s. 111-113.

39 P. Starobin, Gospodarka na ropę, „BusinessWeek - Edycja Polska” 2002, nr 1(118), s. 27. 
ne do zwiększenia produkcji, dążąc do osiagnięcia uprzywilejowanej pozycji na rynkach zagranicznych. Konsekwencją planowanego zwiększenia produkcji jest naturalny spadek ceny ropy na rynku surowcowym. $\mathrm{Na}$ skomplikowaną sytuację wpływ wywierały uwarunkowania międzynarodowe, wyrastające ze sporu między Organizacją Państw Eksportujących Ropę, skupiającą eksporterów surowca zmierzających do ograniczenia produkcji ropy, a państwami zachodu, będącymi głównymi konsumentami paliw. Wzrost cen ropy naftowej mógłby realnie osłabić szanse państw europejskich na wyjście ze stanu spowolnienia gospodarki. W. Putin zadeklarował dostawy ropy, zapewniające stabilizację ceny na giełdzie surowcowej. Obietnica prezydenta może spowodować kryzys gospodarczy, jednakże w długim okresie nastąpi napływ inwestycji bezpośrednich, wynikający z przychylności zachodnich rządów i przedsiębiorstw, rekompensujący ewentualne skutki spowolnienia gospodarki państwowej.

Największe problemy w nowej sytuacji mogą dotknąć przemysł motoryzacyjny i niewydajny sektor rolniczy ${ }^{40}$. Po podpisaniu przez W. Putina ustawy zezwalającej na obrót gospodarczy ziemią, intensyfikacji nabrał handel, wpływając pozytywnie na produkcję i modernizację w sektorze rolnym. Do czasu kryzysu z powodu zawyżonego kursu rubla, korzyści odnoszono z importu żywności. Obecnie sytuacja uległa zmianie i opłacalna stała się produkcja na rynek wewnętrzny. W niewielkich gospodarstwach rolnych, których powierzchnia wynosi $4 \%$ ziem uprawnych, nastał okres produkcji warzyw. Prywatne gospodarstwa farmerskie zapewniają ponad połowę produkowanej wołowiny i wieprzowiny, większość ziemniaków i warzyw.

W 1990 r. w ZSRR wyprodukowano $120 \mathrm{mln}$ ton zboża, z zagranicy sprowadzono dodatkowe $47 \mathrm{mln}$. Był to największy w historii import zboża. W 2001 r. wystapiła nadprodukcja i zdecydowano się na eksport $6,8 \mathrm{mln}$ ton zboża ${ }^{41}$. Rosja pierwszy raz od rewolucji październikowej wyeksportowała zboże - przed przewrotem była jego największym dostawcą na rynki światowe ${ }^{42}$.

Obecną sytuacją w rolnictwie zainteresowały się największe koncerny niezwiązane z produkcją rolną: Łukoil i Gazprom. Powstaje problem, czy reforma rolnictwa, która miała przyczynić się do likwidacji niedostatków

40 D. J. O'Brien, V. Paciorkovskij, L. D. Dershem, Household capital and the agrarian problem in Russia, Aldershot 1999.

41 A. Zaucha, Rosyjski spichlerz, „Newsweek Polska” 2002, nr 35, s. 30-32.

42 P. Kennedy, Mocarstwa Świata ..., s. 476. 
ekonomicznych na wsi, nie wzmocni potentatów, którzy w nowej sytuacji staną się właścicielami sowchozów, a chłopi pozostaną pracownikami najemnymi. Istnieje zagrożenie, że zatrzymanie procesu parcelacji ziemi przyczyni się do pauperyzacji wsi. Zahamowany zostanie proces wzrostu świadomości obywatelskiej społeczeństwa.

Sektory: bankowy i ubezpieczeniowy wymagają radykalnych reform ${ }^{43}$. „W Rosji istnieje około 1300 banków, jednak programów kredytowania małych przedsiębiorstw i innych podstawowych usług bankowych właściwie brak" "44 - sądzi E. Wallace, dyrektor w Europejskim Banku Odbudowy i Rozwoju. Środki finansowe gromadzone przez społeczeństwo przechowywane są w gospodarstwach domowych, czego skutkiem jest niski mnożnik kreacji pieniądza i w konsekwencji brak środków płatniczych na kredyty dla małych przedsiębiorstw. Całkowite depozyty ludności i przedsiębiorstw pozostają na niskim poziomie $3-4 \%$ produktu krajowego brutto. Przedsiębiorcy poszukują środków finansowych za granica, m.in. w Europejskim Banku Odbudowy i Rozwoju. Od 1994 r. około 35 tysiącom rosyjskich przedsiębiorstw bank pożyczył $540 \mathrm{mln}$ USD. Obecnie udziela miesięcznie 2250 kredytów, których wysokość oscyluje od 5 tys. do 10 tys. $\mathrm{USD}^{45}$.

Banki udzielają kredytów agencjom państwowym i konglomeratom kierowanym przez oligarchów. Bank Centralny posiada udziały w 23 bankach komercyjnych i mało prawdopodobna jest rezygnacja banku z obsługi businessu. Banki kredytują 3\% inwestycji, a zapotrzebowanie na usługi bankowe w Rosji jest większe, gdyż gospodarka posiada podstawy do rozwoju i wzrostu. Należy podjąć działania zmierzające do wyegzekwowania od banków ubezpieczenia depozytów, rozwinięcia sieci bankowości detalicznej i odpowiedniego przeszkolenia personelu. Oszczędności Rosjan powinny być lokowane w bankach, co stworzyłoby możliwość rozwoju przedsiębiorstw korzystających z kredytów. Konieczny jest proces konsolidacji banków i dokapitalizowania ich środkami zagranicz-

${ }^{43}$ Por. H. Żukowska, Przyczyny i skutki kryzysu w systemie bankowym Rosji w 1998 roku, „Annales Universitatis Mariae Curie-Skłodowska. Sectio. H Oeconomia" 2001, Vol. 35, s. 35-58; L. Bartosik, Agencja ds. Restrukturyzacji Instytucji Kredytowych - forma zaangażowania państwa w zwalczanie skutków kryzysu systemu bankowego Federacji Rosyjskiej, „Zeszyty Naukowe Wyższej Szkoły Bankowości Wrocław" 2001, nr 1, s. 101-113.

${ }^{44}$ C. Belton, Nie ma co liczyć na reformę rosyjskiej bankowości, „BusinessWeek Edycja Polska” z 09.2001, nr 9(114), s 40.

${ }^{45}$ Ibidem. 
nymi $^{46}$. Istnieje szansa, że odpowiednio działający system bankowy stanie się źródłem powstania i rozwoju klasy średniej - podstawy społeczeństwa obywatelskiego.

W Chabarowsku, położonym niedaleko granicy z Chinami, gubernator W. Iszajew rozwija intrygującą formę gospodarowania, stanowiącą ogniwo łączące gospodarkę centralnie sterowaną w stylu radzieckim, niskowydajną i materiałochłonną, a wolnorynkową. Twierdzi on, że państwo powinno pomóc $\mathrm{w}$ budowaniu gospodarki rynkowej ${ }^{47}$. „Proces pomocy wygląda następująco: administracja Iszajewa przejmuje pakiet kontrolny w zadłużonych przedsiębiorstwach, które były nieefektywnie zarządzane lub okradane przez pierwszych właścicieli, następnie z pomocą lokalnego banku, należącego częściowo do władz Chabarowska, otrzymują wsparcie finansowe i bodziec do wprowadzenia właściwych zasad biznesowych. Na końcu posiadane nieruchomości zostają sprzedane lub przekazane inwestorom strategicznym, którzy zobowiązują się pomnożyć kapitał"48. Metoda zastosowana przez gubernatora chwalona jest przez prezydenta i stosowana w sąsiednich prowincjach. Powstaje pytanie, czy uzdrowione przedsiębiorstwa nie staną się zakładami pracy chronionej, uniemożliwiając niezbędną restrukturyzację? Istnieje możliwość sprzedaży przedsiębiorstwa politycznym towarzyszom.

Sposób gospodarowania sprawowany przez gubernatora stanowi rozwiązanie tymczasowe, wprowadza elementy racjonalności na poziomie mikroekonomii, co może zaprocentować wzrostem świadomości pracowników. Powszechne stosowanie nacjonalizacji upadających przedsiębiorstw opóźni rozwój Rosji w wyniku zablokowania makroekonomicznych mechanizmów rynkowych.

Rosja, Ukraina i kraje bałkańskie tworzą cywilizację prawosławną region geograficzny i kulturalny odmienny od pozostałych obszarów świata zachodu ${ }^{49}$. Elementami integrującymi narody są kultura, tradycja, obyczaje powstałe za sprawą Cerkwi prawosławnej i poczucia przynależności do grupy narodów słowiańskich. Cerkiew była obiektem prześladowania w czasach komunizmu, a apogeum wymierzonych przeciwko

46 H. Żukowska, M. Żukowska, Gospodarka i systemy bankowe w wybranych krajach Europy Środkowej, Lublin 1999, s. 70-81.

47 P. Starobin, R. Working, Kapitalizm hybrydowy w praktyce, „BusinessWeek Edycja Polska" 2001, nr 10(115), s. 80.

48 Ibidem, s. 80-81.

49 P. Bracken, op. cit., s. 134. 
niej działań przypada na okres sprawowania totalitarnych rządów przez Józefa Stalina - Gruzina, pierwszego sekretarza KPZR w latach 1924-1953. W celu umocnienia władzy zlecał on masowe „czystki” wyimaginowanych wrogów ustroju. Jednymi z nich byli popi - duchowni prawosławni, stanowiący przeszkodę w budowie państwa komunistycznego i wizerunku wszechmocnego wodza. Mimo wrogiego nastawienia do kościoła ortodoksyjnego, w czerwcu 1941 roku, Stalin, mając na uwadze religijność narodu, odwołał się w swoim wystąpieniu do kulturotwórczej roli religii. Społeczeństwo odebrało słowa dyktatora jako zapowiedź kresu polityki terroru. Działanie Stalina było świadomym wykorzystaniem religijności narodu do jego mobilizacji w obronie państwa przed III Rzeszą.

W październiku 1990 r. Rada Najwyższa uchwaliła ustawę o wolności sumienia i organizacjach religijnych stanowiącą jakościową zmianę w systemie prawnym państwa radzieckiego. W grudniu $1990 \mathrm{r}$. uchwalono ustawę o wolności wyznań, która obowiązuje do czasów współczesnych w Federacji Rosyjskiej. W nowych rozwiązaniach prawnych uznano prawo do wyznawania własnej wiary, kładąc kres dyskryminacji wiernych ${ }^{50}$.

W okresie komunizmu część społeczeństwa wybrała ateizm będący warunkiem awansu społecznego. Spadkiem po komunizmie jest w Rosji największa w porównaniu $\mathrm{z}$ cywilizowanym światem liczba zabójstw, aborcji, rozwodów, bezdomnych dzieci. Putinowi zależy na odnowieniu moralności Rosjan i wypełnieniu pustki duchowej po komunizmie ${ }^{51}$. Powstaje pytanie, czy Cerkiew nadaje się do realizacji planu Putina? Cerkiew jest instytucją skompromitowaną i niepopularną, powiązaną z władzą i kojarzoną z korupcją, a Aleksiej II, Patriarcha Moskwy i Wszechrusi, postrzegany jest jako były agent służb bezpieczeństwa wewnętrznego. Z retoryki przedstawicieli Cerkwi wyłania się obraz Rosji jako kraju otoczonego przez wrogów dążących do pozbawienia Rosjan prawosławnej duszy $^{52}$.

„Bardziej niż bezdomne dzieci Cerkiew interesuje walka o podtrzymanie mitu III Rzymu"53 - twierdzi W. Materski, ekspert w sprawach rosyjskich, wicedyrektor Instytutu Studiów Politycznych Polskiej Akademii

50 E. Zieliński, Współczesna Rosja - studium polityczno-ustrojowe, Warszawa 1995, s. 48.

51 J. Urbański, Czystki religijne, „Wprost” z dn. 5.05.2002, nr 18, s. 18-23.

52 G. Ślubowski, Święta Ruś, ,,Wprost” z dn. 28.04.2002, nr 17, s. 116-117.

53 Ibidem. 
Nauk. Władze Cerkwi gotowe są bronić wpływów w społeczeństwie, posuwając się w działaniach do niekonwencjonalnych metod ${ }^{54}$. Aleksiej II za wroga Świętej Rusi postrzega Kościół katolicki, zmierzający do umocnienia pozycji w Rosji5 ${ }^{5}$. W Nowosybirsku i Pskowie odbyły się demonstracje antykatolickich; w Dumie pojawiła się uchwała, w której wzywano

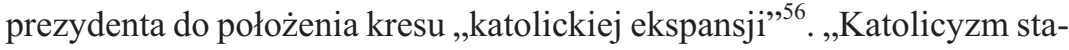
nowi zagrożenie dla Cerkwi, oferując atrakcyjniejszy niż w prawosławiu model cywilizacyjny. W katolickich parafiach kościoły są czyste i zadbane, rozwija się życie kulturalne i wierni otrzymują dary. Upowszechnienie łacińskiego modelu cywilizacyjnego znacznie zmniejszyłoby uległość obywateli wobec państwa" ${ }^{, 57}$.

Zagrożenie dla Cerkwi stanowi islam, który zdobywa w obrębie Federacji Rosyjskiej znaczące wpływy. Narody muzułmańskie umacniają pozycję w państwie ${ }^{58}$, wiarę w Mahometa przyjmuje około 100 tys. Rosjan rocznie. Islam jest religią młodych i dynamicznych ludzi, w przeciwieństwie do prawosławia, gdzie spośród ponad 100 mln wiernych w nabożeństwach uczestniczy $6 \mathrm{mln}$, głównie w podeszłym wieku. Władze państwa inspirowane przez Cerkiew zabraniają budowy meczetów; wojnę w Czeczenii, niewielkim kaukaskim kraju walczącym o niepodległość, popi przedstawiają jako wojnę $\mathrm{z}$ islamskim fundamentalizmem ${ }^{59}$.

Czym Putin wypełni pustkę duchową w społeczeństwie po upadku komunizmu? Cerkiew jest instytucją skompromitowaną, niemogącą posłużyć jako instrument odbudowy wizerunku rządzących. Nie przydaje władcom świętości, jak za czasów carskich, kiedy to legitymowała prawo carów do rządów absolutnych. Wraz z G. Pawłowskim, doradcą i specjalistą od public relation, Putin zaczął kreować nowy wizerunek Ojca Narodu, nawiązując do czasów carskich i komunistycznych. Wielu Rosjan uwierzyło w „,cara i sekretarza” - Władimira Putina. Prezydent wykorzystał tęsknotę za silną władzą po nieudolnych rządach Borysa Jelcyna.

54 Por. W. Stankiewicz, Ewolucja autokefalicznego Kościoła prawosławnego, „Gdańskie Studia Międzynarodowe” 2005, Vol. 4, nr 1-2, s. 53-70.

55 S. J. Rostworowski, Zżycia kościelnego w Rosji i na Wschodzie, ,Studia i Dokumenty Ekumeniczne" 2001, nr 1, s. 57-68.

56 Por. A. Rachalski, Prawowiercy i krzywowiercy, „Bez Dogmatu” 2001, nr 49, s. 27.

57 J. Urbański, Czystki religijne ..., op. cit., s. 20.

58 V. Suchanov, Muzutmanie, Wahabici, Rosja, „Sprawy Polityczne” 2001, nr 4, s. $87-94$.

59 W. Stankiewicz, Zasada integralności terytorialnej ..., s. 9-28. 
Wzrost popularności prezydenta przyczynił się do powstania organizacji młodzieżowej o nazwie Idący Razem, której celem jest popularyzacja pomysłów Putina oraz uczestnictwo w spotkaniach prezydenta ze społeczeństwem. Młodzieżówka finansowana jest przez oligarchów pragnących utrzymać wpływy na Kremlu ${ }^{60}$.

Formy kultu Putina przybierają różnorodne kształty. We wsi Krasnyj Sad w pobliżu Rostowa nad Donem na pamiątkę wizyty prezydenta zbudowano kaplicę. O. Jaruszyn, student z Czelabińska napisał Pieśń o prezydencie $^{61}$. Organizowane są wystawy na cześć prezydenta, tworzone są popiersia, kalendarze, portrety, powstają też książki poświęcone prezydentowi. Największym uwielbieniem Putina popisali się 20 sierpnia 2002 r. deputowani lokalnego parlamentu z dalekiego Magadanu (rosyjskiego Dalekiego Wschodu), którzy zwrócili się do Dumy Państwowej z propozycją zmian w konstytucji umożliwiających przedłużenie kadencji obecnego prezydenta $\mathrm{z} 4$ do 7 lat $^{62}$.

Putin osiagnął sukces Od początku sprawowania rządów przyjmował dwa oblicza: na potrzeby Zachodu - zręcznego menadżera, technokraty i pragmatyka; dla Rosjan wykreował wizerunek prezydenta o zatroskanej twarzy cara - bartiuszki, ojca narodu. Zyskał on osiemdziesięcioprocentową akceptacją społeczeństwa i zdaje się być konieczny czy pomocny przy zwalczaniu problemów wewnętrznych.

Do istotniejszych problemów Rosji zalicza się kwestię integralności państwa, które jest wielonarodowościowym i wielowyznaniowym tworem. Konfliktowymi regionami są Kaukaz ${ }^{63}$ (Czeczenia), Syberia, południowo-wschodnia część Rosji ${ }^{64}$. Czeczeni od lat walczą o uzyskanie wolności, choć okres komunizmu zahamował dążenia niepodległościowe. W 1994 r. konflikt odrodził się, przybierając niebezpieczną formę i stanowiąc zagrożenie dla całego społeczeństwa.

Czeczeni, oprócz walki partyzanckiej z armią rosyjską, stosują terroryzm. Pamiętane są wydarzenia z czerwca 1995 r., kiedy oddział party-

60 M. Kacewicz, Car Wtadimir, „Newsweek-Polska” z dn. 1.09.2002, nr 35, s. $28-30$.

61 G. Ślubowski, Władimir Iljicz Putin, „Wprost” z dn. 14.04.2002, nr 15, s. $100-101$.

62 M. Kacewicz, op. cit., s. 28-30.

63 Por. W. Michałowski, Płonqcy Kaukaz, Wrocław 2000; M. Kuleba, Imperium na kolanach. Wojna w Czeczenii 1994-1996, Warszawa 1998.

64 P. Bracken, op. cit., s. 41. 
zancki dokonał ataku zbrojnego na szpital w Budionnowsku ${ }^{65}$; z 2000 r., kiedy eksplodowały ładunki wybuchowe podłożone pod budynki mieszkalne w Moskwie, Wołgodońsku i Bujnansku, czy te z teatru na Dubrowce. Bezwzględność Putina w czasie działań w Czeczenii zadecydowała o popularności prezydenta. Społeczeństwo w $85 \%$ poparło decyzję o przeprowadzeniu akcji uwolnienia zakładników. Zadziałał mechanizm zakorzeniony w podświadomości władz, ukazujący społeczeństwu skuteczność w walce z terrorystami, wrogami społeczeństwa. Wartość życia jednostki nie okazała się znacząca. Nie wykorzystano możliwych metod negocjacji, chociaż istniały merytoryczne podstawy odstapienia przez Czeczenów od przetrzymywania zakładników. Zastosowanie śmiertelnego gazu jest przejawem radzieckiego stylu działania służb specjalnych, stosowanego w Czeczenii, gdzie odnotowano przypadki ludobójstwa. Nie ulega wątpliwości, że Putin realną władzę buduje na koncentracji służb specjalnych i resortów siłowych, w których pełnił służbę. Znany jest konflikt prezydenta z wolnymi mediami, telewizją NTV i ORT oraz krytycznie nastawionymi wobec polityki Kremla oligarchami: B. Bieriezowskim i W. Gusinskim.

Putin skutecznie buduje w państwie model autokratyczny - odwołuje się do przeszłości, nie jest zainteresowany przedstawieniem obywatelom alternatywnego modelu państwa i społeczeństwa. „Kreml podejmuje istotne decyzje kadrowe, kontroluje najważniejsze środki masowego przekazu i skutecznie przeciwdziała powstawaniu znaczącej opozycji politycznej" ${ }^{66}$ - zauważa M. Menkiszak, ekspert Ośrodka Studiów Wschodnich. Putin wspominał o potrzebie wprowadzenia „dyktatury prawa”. Budowany ustrój państwa z liberalnym modelem demokracji jest niespójny i bliższy rozwiązaniom wschodnioazjatyckim ${ }^{67}$. Powstaje pytanie, dlaczego prezydent silnie podkreśla związek z Zachodem? Czy Rosja potrzebuje inwestycji bezpośrednich, aby przez wzrost gospodarczy dołączyć do światowej elity?

Rosja jako spadkobierczyni ZSRR nie posiada realnego wpływu na międzynarodową politykę, chociaż dysponuje arsenałem broni masowego rażenia i strategicznym położeniem geograficznym ${ }^{68}$. Graniczy z pań-

65 Najnowsza Historia Świata, op. cit., s. 96-102.

66 J. Urbański, G. Ślubowski, A. Koziński, Życie za kopiejkę, „Wprost” 2002, nr 45 , s. 98.

67 Ibidem, s. 94-100.

68 W. Stankiewicz, Uwarunkowania polityczno-militarne federacji rosyjskiej a bezpieczeństwo międzynarodowe ..., s. 393-410. 
stwami przechodzącymi przeobrażenia polityczne i gospodarcze; sąsiaduje z konfliktogennymi regionami świata, będącymi zagrożeniem dla pokoju $^{69}$. Paradoksalnie Rosja odniosła korzyść w wyniku tragicznych wydarzeń z 11 września 2001 r. G.W. Bush, prezydent USA, wezwał demokratyczne państwa do przeciwstawienia się terrorystom, jednak sojusznicy z Paktu Północnoatlantyckigo (NATO) nie są skłonni udzielić wsparcia militarnego. Tymczasem Rosja, obiecując współpracę obejmującą wymianę tajnych informacji, stała się jednym z filarów koalicji antyterrorystycznej. Odwróciła przy tym uwagę obserwatorów od swoich działań w Czeczenii, które w terminologii politycznej określane są terminem: „terroru politycznego”, polegającego na eksterminacji walczących o wolność. Upowszechniła się postawa nie ujmowania się za separatystami, chociaż wedle zasad prawa narodów zawartych w fundamentalnych dokumentach Organizacji Narodów Zjednoczonych, mogą oni prowadzić działania zmierzające do uzyskania niepodległości. Dyplomaci i uczeni na Zachodzie rzadko powołują się na zasadę samostanowienia, a coraz powszechniej na zasadę nienaruszalności granic. Utrzymywanie status quo ma pierwszeństwo przed dążeniami wolnościowymi ${ }^{70}$. Współczesnymi terrorystami są dawni partyzanci, powstańcy czy bojownicy o wolność ${ }^{71}$.

Dla obywateli cywilizowanych państw skutkiem wydarzeń z USA jest rozszerzenie uprawnień sił wywiadowczych i specjalnych. W Rosji zachwiana została równowaga między prawami obywatelskimi a bezpieczeństwem państwa. Szala przechyliła się na stronę wzmocnienia bezpieczeństwa $^{72}$. Wizję demokratyzacji Rosji odsunięto w czasie.

Putin prowadząc politykę zagraniczną poszukiwał wsparcia na kontynencie $^{73}$. W czasie wystąpienia w Reichstagu, niemieckim parlamencie, stwierdził, że Europa dopiero wtedy stanie się centrum polityki światowej, gdy połączy doświadczenie i technologie z rosyjskim potencjałem gospodarczym $^{74}$. Obydwa państwa dążą do osiagnięcia partykularnych

${ }^{69}$ E. Zieliński, op. cit., s. 257.

70 W. Giełżyński, Oś Moskwa - Pekin, „Wprost” 2001, nr 48, s. 102-103.

${ }^{71}$ B. Hoffman, Oblicza terroryzmu, Warszawa 2001, s. 26-27.

72 W. Jerofiejew, Rosja - kraj o niezbyt otwartej przyszłości, „Newsweek-Polska” 2002, nr 37, s. $50-52$.

${ }^{73}$ Por. S. Żerko, Niemcy wobec Rosji na przetomie stuleci, „Przegląd Zachodni” 2001, nr 3, s. 103-123; E. Cziomer, Polityka Republiki Federalnej Niemiec wobec Wspólnoty Niepodleglych Państw u progu XXI wieku ze szczególnym uwzględnieniem miejsca i roli Rosji, „Państwo i Społeczeństwo” 2001, nr 1, s. 59-78.

74 P. Cywiński, Zdobycie Reichstagu, „Wprost” 2001, nr 40, s. 96-97. 
celów: Rosja poszukuje rzecznika interesów na kontynencie, Niemcy z kolei oczekują, że Rosja poprze ich dążenia mające na celu poszerzenie kręgu stałych członków w Radzie Bezpieczeństwa.

Sukcesem rosyjskiej dyplomacji jest utworzenie Rady NATO-Rosja. Rada ta została utworzona jako organ porozumiewawczy i koordynacyjny do wspólnych działań w walce z terroryzmem. Jest kontynuacją wspólnej polityki państw cywilizowanych przeciw terroryzmowi. Pierwszym dokumentem, w którym potwierdzono współpracę, był Akt NATO-Rosja z 27 maja 1997 r. Stworzono ramy dla partnerstwa w sferze bezpieczeństwa i budowy stabilizacji na świecie ${ }^{75}$. Rada powstała na skutek niezdolności państw sojuszniczych NATO do wspólnego działania. Organizacja przeżywa kryzys objawiający się odmiennością interpretacji podpisanej umowy członkowskiej dotyczącej udzielenia pomocy sojusznikowi w razie ataku zbrojnego nieprzyjaciela. USA, analizując sytuację zażądało od państw członkowskich zwiększenia środków finansowych na modernizację armii.

Putin, mimo oficjalnego współdziałania z Bushem, prowadzi współpracę gospodarczą z państwami określanymi przez USA, jako kraje „osi zła”. Kontrakt z Irakiem szacowany jest na 40-60 mld USD i dotyczy realizacji ponad siedemdziesięciu projektów (od produkcji żywności do wyposażenia technicznego pól naftowych). Najwięcej obaw państw zachodnich budzi rozszerzenie pomocy przeznaczonej na budowę reaktorów jądrowych w Iranie czy współpraca z Kim Dzong Ilem, przywódcą Koreańskiej Republiki Ludowej ${ }^{76}$.

Kreml w polityce przyjmuje niekonsekwentne stanowisko - nie wyraża publicznie dezaprobaty dla terroryzmu, jak czynił to po atakach wojsk rosyjskich na Czeczenię. Powstają wątpliwości, czy współpraca z państwami popierającymi terrorystów stanowi próbę zapobieżenia rozszerzeniu wpływów amerykańskich i czy Rosja, wypracowanym stanowiskiem i działaniem, pragnie wzmocnić swoją pozycję wywierając na forum międzynarodowym presję polityczną na USA.

Podstawą działalności rosyjskiej są wpływy gospodarcze koncernów energetycznych. Putin odrzucił propozycję A. Łukaszenki, prezydenta Białorusi, równoprawnego połączenia obu państw. Zaproponował natomiast przyłączenie, mając na uwadze aspiracje białoruskiego prezydenta

75 E. Latoszek, M. Proczak, Organizacje międzynarodowe, Warszawa 2001, s. 521 .

76 C. Caryl, Podać rękę diabłu, „Newsweek-Polska” 2002, nr 35, s. 33-34. 
oraz postępujący proces integracji, rozpoczęty w styczniu 1995 r. podpisaniem układu o przyjaźni i współpracy ${ }^{77}$. Na początku listopada $2002 \mathrm{r}$. rosyjski Gazprom zapowiedział zmniejszenie o połowę dostaw gazu na Białoruś, ze względu na zaległości płatnicze na kwotę $200 \mathrm{mln} \mathrm{USD}^{78}$. Tym samym Białoruś znalazła się w niekorzystnej sytuacji energetycznej.

Problemem dla Rosji pozostaje tranzyt z Kaliningradu ${ }^{79}$. Pomoc zaoferowała Unia Europejska (UE), która w czasie członkostwa Litwy i Łotwy w UE, przyznała obywatelom rosyjskim prawo do swobodnego - bez wiz, jedynie na podstawie specjalnych biletów wydawanych na dworcach kolejowych - przemieszczania się po terytorium obu państw. Zarządzenie Unii jest pogwałceniem suwerenności Litwy i Łotwy - stanowi propozycję członkostwa trzeciej kategorii ${ }^{80}$.

Rosja dysponuje skutecznym instrumentem oddziaływania na politykę Litwy, Łotwy i Estonii. Manipulowanie dostawą surowców energetycznych jest skutecznym narzędziem kreowania sytuacji politycznej w republikach. W 1992 i 1998 r. groźba wstrzymania przez rosyjski koncern dostaw ropy naftowej znacząco wpłynęła na wynik wyborów parlamentarnych na Litwie i Łotwie. Państwa b. ZSRR decydują o warunkach tranzytu rosyjskiego gazu oraz zarządzają podziemnymi zbiornikami, z których w sezonie zimowym czerpie gaz Obwód Kalingradzki ${ }^{81}$.

Na podstawie analizy problemu zmian zachodzących w Rosji po upadku komunizmu można sformułować następujące uogólnienia:

1. Rosja odziedziczyła problemy właściwe dawnemu mocarstwu, będącemu skupiskiem wielu narodów, religii i wyznań. ZSRR, stosując terror, skutecznie likwidował wystapienia narodowowyzwoleńcze. Obecnie wielonarodowość połączona z decentralizacją władzy skutkowałaby podziałem państwa - odłączyłyby się narody o silnych dążeniach niepodległościowych (Czeczenia), tereny zdominowane przez imigrantów (Rosja południowo-wschodnia zasiedlona przez Chińczyków) czy rejony, które w przeszłości decydowały się na samodzielność (Syberia). Dodatkowym czynnikiem dezintegrującym jest podział na

77 Rosja i jej squsiedzi ..., s. 20.

78 C. Goliński, Gazowy uścisk, „Gazeta Wyborcza” z dn. 4.11.2002.

79 R. Rybiński, Marzenie o Hongkongu, „Nowe Państwo” 2002, nr 4, s. 5-7.

80 J. M. Nowakowski, Nasza mała geopolityka, ,Wprost” 2002, nr 31, s. 84-87.

81 Por. K. Pełczyńska-Nałęcz, Kondycja i perspektywy rosyjskiego sektora gazowego, „Prace OSW” 2001, nr 1, s. 5-11, 29-35; G. Gromadzki, Stosunki Rosji z państwami bałtyckimi, Kraków 2000, s. 49. 
społeczeństwo wielkich miast o poglądach liberalnych, gotowe na przyjęcie reform oraz społeczeństwo wsi i prowincji, które nie odczuwa potrzeby zmian, reprezentuje idee komunistyczne i nacjonalistyczne.

2. Komunistyczna Partia Federacji Rosyjskiej traci znaczenie polityczne. Sytuację tę potęgują plany Kremla, dążącego do stworzenia dwupartyjnego modelu parlamentarnego. Ugrupowaniem prawicowym stanie się Jedność Rosji, a po lewej stronie superpartia utworzona przez G. Sieleznowa, przewodniczącego Dumy. Miejsca w parlamencie dla KPFR nie przewidziano. Plany Kremla jawią się jako działania antydemokratyczne, zmierzające do pozbawienia opozycji wpływu na władzę w państwie.

3. W 1991 r. powstała Wspólnota Niepodległych Państw, jako organ współpracy między byłymi republikami mocarstwa. W praktyce prace organizacji odbywały się pod hasłem ,wszyscy przeciw Rosji” i kończyły się niespełnionymi deklaracjami politycznymi. Niemożliwa jest restauracja ZSRR, gdyż prezydenci republik nie są zainteresowani podporządkowaniem się zwierzchnictwu Kremla.

4. Wydarzenia z 11 września 2001 r. pozytywnie wpłynęły na rosyjską politykę zagraniczną. Przystąpienie Rosji do koalicji antyterrorystycznej i zaoferowanie współpracy wywiadów uczyniły z Putina sojusznika G. W. Busha. Kryzys w NATO umożliwił utworzenie Rady NATO-Rosja, która jest dowodem sukcesu dyplomacji rosyjskiej. Przyjęcie Rosji do Paktu, ze względu na sprzeczność interesów i prawo Moskwy do wetowania rozporządzeń, byłoby początkiem upadku organizacji.

5. Rosjanie, współpracując z Niemcami, które pełnią rolę rzecznika interesów Rosji w Europie, prowadzą aktywną politykę na kontynencie. Unia Europejska, zgadzając się na bezwizowy tranzyt z Kaliningradu do Rosji przez Litwę i Łotwę, przyczyniła się do ograniczenia suwerenności państw bałtyckich; propozycja wstapienia do Unii Europejskiej skierowana do tych państw okazała się być synonimem członkostwa trzeciej kategorii.

\section{Summary}

On the basis of analysis of the transformations occurring in Russia following the collapse of Communism, the Author proposes a research hypothesis in terms of three statements. Firstly, Russia is creating the foundations for the development of a market economy, yet this process is hardly dynamic and has not involved all the branches of the economy. Secondly, there are no symptoms to demonstrate that a civic society is 
emerging in Russia, with tradition playing a significant role in how the relations between the elements and social institutions are perceived. Thirdly, the Kremlin's foreign policy is not clearly formulated, and no transparent strategy or clear objectives have been worked out. 